IZA DP No. 4641

The Determinants of High School Closures:

Lessons from Longitudinal Data throughout Illinois

Sherrilyn M. Billger

Frank D. Beck

December 2009 


\title{
The Determinants of High School Closures: Lessons from Longitudinal Data throughout Illinois
}

\author{
Sherrilyn M. Billger \\ Illinois State University \\ and IZA
}

\author{
Frank D. Beck \\ Illinois State University
}

\section{Discussion Paper No. 4641 \\ December 2009}

\author{
IZA \\ P.O. Box 7240 \\ 53072 Bonn \\ Germany \\ Phone: +49-228-3894-0 \\ Fax: +49-228-3894-180 \\ E-mail: iza@iza.org
}

Any opinions expressed here are those of the author(s) and not those of IZA. Research published in this series may include views on policy, but the institute itself takes no institutional policy positions.

The Institute for the Study of Labor (IZA) in Bonn is a local and virtual international research center and a place of communication between science, politics and business. IZA is an independent nonprofit organization supported by Deutsche Post Foundation. The center is associated with the University of Bonn and offers a stimulating research environment through its international network, workshops and conferences, data service, project support, research visits and doctoral program. IZA engages in (i) original and internationally competitive research in all fields of labor economics, (ii) development of policy concepts, and (iii) dissemination of research results and concepts to the interested public.

IZA Discussion Papers often represent preliminary work and are circulated to encourage discussion. Citation of such a paper should account for its provisional character. A revised version may be available directly from the author. 
IZA Discussion Paper No. 4641

December 2009

\section{ABSTRACT \\ The Determinants of High School Closures: Lessons from Longitudinal Data throughout Illinois ${ }^{*}$}

Facing substantial financial pressure, many districts close schools in order to preserve solvency and improve student outcomes. Using a new longitudinal data set on all non-Cook County Illinois schools, we examine the determinants of high school closure decisions from 1991 through 2005. Our dataset combines information from a wide variety of sources, including the Illinois State Board of Education, the Census Bureau, the Illinois Department of Revenue, and the Bureau of Labor Statistics. Prior studies in this area typically use crosssectional data, short panels, or case-studies. Schools that close have lower enrollments, are located in more rural areas, and have higher per-pupil expenditures. Enrollments and fiscal resources are indeed the most important determinants of school closures. Neither math and reading test scores nor the sociodemographics of the students have a significant impact on high school closure decisions.

JEL Classification: $122,121, \mathrm{~J} 24$

Keywords: economics of education, education finance, human capital, secondary education

Corresponding author:

Sherrilyn M. Billger

Department of Economics

Illinois State University

Campus Box 4200

Normal, IL 61790-4200

USA

E-mail: smbillg@ilstu.edu

\footnotetext{
This project is supported by the Cooperative State, Research, and Extension Service, U.S. Department of Agriculture, under award No. ILLR-2006-03018. We thank Norman Durflinger, Joseph Pacha, and Lynne Curry for their expertise with Illinois schools and their assistance in gathering the data. We are also grateful for the research assistance provided by Jenna Bertschi, Eric Cheriyuot, Bishal Kasu, and especially Brandon Curtis.
} 


\section{Introduction}

School district and community leaders pursue consolidation and school closure for a variety of fiscal and educational reasons, such as declining enrollments, curricular weakness, lack of tax revenue, rising administrative costs, or any combination of these and other factors. In the face of such forces, a decision to close a school may seem the best choice to some. However, others voice concern for the health of the local economy and a loss of cultural identity precipitated by a closure or consolidation. ${ }^{1}$ The battles within and between communities over these decisions can be fierce.

However, it is difficult to gather quality data for school closure studies. Recent quantitative studies use cross-sectional data or short panels and the limited variables used do not reflect the numerous other related predictors which may affect the outcome. Longer term in-depth analyses of the trends that shape closure decisions have not occurred. We do not know the relative effect of demographic characteristics, economic conditions, and school fiscal resources on the likelihood of closures. Consequently, this paper is the first in a series which propose a longitudinal view of school district reorganization using far more predictors than seen in previous studies. While this paper is part of a larger project that examines closures and the outcomes of these decisions, here we propose to study the first question: What are the demographic, economic, and educational predictors of rural school closure? What is the relative importance of school and community characteristics?

\section{The Debate Over District Consolidation and School Closure}

Since at least 1896, rural schools have been seen as wasteful and inferior (Kannapel and DeYoung 1999). Over the course of the last century school systems have been centralized, with their control

\footnotetext{
${ }^{1}$ District consolidations often lead to a school closure, district reorganization can close a high school and open a junior high in the same building, and districts can downsize by closing a school. With the school as the unit of analysis, we refer to all such actions as "closures."
} 
placed in the hands of professionals. In Illinois the 11,000 schools districts in 1940 were whittled down to 879 today. According to a scientific management/economies of scale philosophy, production costs should be reduced by increasing the size of the facility (Fanning 1995). For instance, as districts fall below 750 students expenditures per pupil rise; yet expenditures per pupil remain flat in districts of over 1,000 students; larger districts can devote more resources to secondary and non-essential activities. Furthermore, larger districts have lower administrative costs and a wider range of curricular offerings (Arnold 2000; Benton 1992; Fanning 1995; Monk and Haller 1986; Nelson 1985). On the other hand, Gordon and Knight (2008) find that district consolidation in Iowa did not improve pupil-teacher ratios, enrollments, or dropout rates.

On the other hand, scale economies can come at the expense of educational quality. Smaller schools have fewer discipline problems, provide more opportunities for leadership development and extracurricular activities and are the focal point of the communities they serve (Benton 1992; Monk and Haller 1986; Nelson 1985; Ramirez 1992). In addition, in small schools students from poor families have higher levels of achievement. Christopher Berry (2003) also states that consolidation implies less local control.

Economists have found that declining population, difficulty raising revenue, and falling property values predict school closure (Brasington 1999; Louisiana Department of Education 2003; Ratcliffe, Biddle, and Yinger 1990). Cross-sectional work by Lyson (2002 and 2005) shows how communities with schools have healthier economies and significantly different demographics than communities without schools. Lastly, community size affects consolidation: larger communities are more willing to merge than smaller places (Brasington 2003).

\section{The Rural Context}


The economic, agricultural, demographic, and familial changes shaping rural America are welldocumented. The corn-belt, of which Illinois is a part, has seen large out-migration that produced an uneven, older age structure. While this trend saw a brief turnaround in the 1970s (Beale 1975) and less so in the 1990s (Economic Research Service 1997; Johnson and Beale 1994), there is a marked long-term decline.

Along with falling population, average farm size has increased and and the number of farms has fallen since the 1930s (Albrecht 1997; Cochran, 1979; Dorner, 1983; Paarlberg, 1980). Some communities offset this trend by developing service or manufacturing employment, but those places that remained dependent on agriculture experienced the greatest decline in population (Beale, 1993; Summers, 1983). However, Edwards (1979) and Hodson (1984) point out that different industrial structures have different consequences for respective communities; rural agricultural counties have the highest employment rates compared to rural industrial or service-dominated counties (Albrecht, 1998).

This century long decline in farming, a short-lived industrial invasion (Summers, Clemente, Evans, Beck, and Minkoff, 1976), and the relative rise in low-skill service jobs yielded low wages and low farm income in the rural work force (Fitchen, 1991; Kassab and Luloff, 1993; McLaughlin, Diane K. and Alisha J. Coleman-Jensen, 2008; Noyelle, 1986; Tickamyer and Duncan, 1990). Some of the most vulnerable rural groups (e.g., single-headed families and minority households) experienced increased hardship (Kassab, Luloff, and Schmidt, 1995; Lichter, Parisi, Grice, and Taquino, 2008). In short, many rural places were "left behind" with struggling economies and associated social disruptions (Foukes, Matt and K. Bruce Newbold , 2008; Gaventa, Smith, and Willingham, 1990; Wilkinson, 1984 and 1986). 
In Illinois, school district revenue is highly dependent on property taxes. Not only do rural school districts experience decreased enrollment due to out-migration and lower birth rates, but the changes in the industrial/agricultural structure negatively affect the tax revenue they rely upon. At a time when rural children may need more services, there is less to give. For instance, poor rural families move more often than those who are more secure. This thinly spreads already depleted district resources (Fitchen 1994; Schafft 2005) and leaves these children even farther behind academically. Furthermore, there is some evidence that the fiscal burden on non-metropolitan governments has surpassed that of the cities (Johnson, Pelissoro, Holian, and Maly 1995). In the face of these trends, it is obvious that school closures are viewed as solutions, even necessities.

\section{Schools and their Communities}

In-depth, historical, and qualitative studies of school closure exist only as case studies (DeYoung 1995; Reynolds 1999). In contrast, we investigate the predictors of rural school closures using a large panel dataset for Illinois. The forces impacting these decisions are diverse. Many are obvious (e.g., declining enrollments) and others are not (e.g., the percent of low income students). We now move to analyze those relationships.

To gain a better understanding of the dynamics of school closures, we use information from a variety of sources over a long period of time. For this analysis we have amassed a large quantity of data for all Illinois schools outside of Cook County from 1991 through 2005. We begin with school and district data from the Illinois State Board of Education. Their database includes a list of all schools that closed since 1986. We have merged this with the overall list of elementary, junior high, and secondary schools for the entire state, excluding Cook County. We have included only regular 
schools, omitting alternative, charter, and juvenile delinquency schools from our study. School data including attendance rates, racial composition, expenditures, tax rates, and test scores are gathered from the Illinois State School Report Card. Our analysis focuses on 548 high schools in Illinois.

We then augment our data with community information from the US Census Bureau. We have some annual data (such as population estimates) and additional data from the 1990 and 2000 Decennial Censuses, for which the intervening years are imputed with a linear trend. Some data are gathered at the place-level, and other information is available for counties. We also include annual county-level unemployment data from the Bureau of Labor Statistics (recent years) and the Illinois Department of Employment Security (earlier years).

Table 1 reports summary statistics for the secondary schools in our analysis. We see significant differences between schools that close and those that do not. Enrollments average 689 in high schools that remain open, but only 202 in schools that eventually close. High schools that close are located in poorer communities, with average statistics such as $22 \%$ low income students, $2 \%$ poverty rate for the community, $\$ 36,000$ lower median house values, and $\$ 8,000$ lower median income. Perhaps to compensate for limited resources, per pupil expenditures are lower, and school tax rates are higher. On the other hand, pupil-teacher ratios are lower, and test scores and attendance rates are virtually identical, suggesting these are not low-quality schools. Unsurprisingly, schools in rural areas are more likely to close. The rural population is $77 \%$ of the total in towns where a high school closes.

We also observe school characteristics in the years preceding a high school closure. These trends are displayed in Figure 1. There is a marked increase in per-pupil expenditures, beginning 7 years before 
the school closes. Around the same time, the education fund declines and the EAV per pupil rises. Starting one year later, school enrollment falls precipitously. During the years before a high school closes, we see a challenging administrative situation for these schools. It is somewhat surprising that the school-age population increases prior to school closure. However, if enrollment happens at the same time, these communities either have a lack of foresight about future enrollment, too much difficulty meeting expenses, or low support for the school (perhaps more students enroll in private schools, for instance).

\section{The Determinants of High School Closure Decisions}

While summary statistics reveal important differences between high schools that close and those that remain open, we are most interested in the marginal effects of school and community characteristics on the probability of school closure. The full model can be written as:

$$
\operatorname{Prob}\left(\text { closes }_{i}=1\right)=f\left(S_{i \oplus} D_{i p} T_{i p} C_{i t}\right)
$$

where closes $=1$ for each secondary school that closes 1991-2005. This is a time-invariant measure that allows us to compare all schools over time. We incorporate multiple time-varying independent variables in the analysis. S denotes school characteristics: student enrollment, racial composition, low income students, and math and reading test scores. $D$ includes district data: pupil-teacher ratio, per pupil expenditures, equalized assessed value, education fund, school tax rate, teacher salary, average teacher experience, and a high school district indicator. ${ }^{2}$ Town characteristics are in $T$ : poverty rate, urban/rural indicators, agricultural employment, immigrant population, median house value, median household income, and owner-occupied housing vacancy rate. County data are in $C$ : community educational attainment, percentage of the population 19 and under, unemployment rate, and whether the county has a property tax cap.

\footnotetext{
${ }^{2}$ Illinois has three types of districts: elementary, high school, and unit.
} 
Equation (1) is estimated with maximum likelihood probit, as follows:

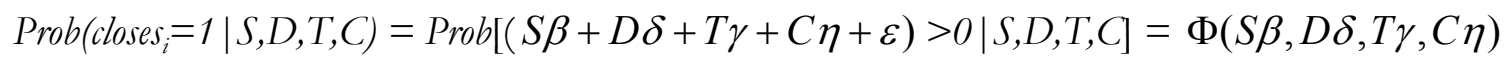

where $\Phi(\bullet)$ denotes the standard normal cumulative distribution function, and $S, D, T, C$ are as defined above. To aid interpretation, we report marginal effects evaluated at the mean of each continuous variable. For example, the marginal effect of enrollment is calculated as:

$$
\frac{\partial \Phi(S \hat{\beta}, D \hat{\delta}, T \hat{\gamma}, C \hat{\eta})}{\text { denroll }}=\phi(\bar{S} \hat{\beta}, \bar{D} \hat{\delta}, \bar{T} \hat{\gamma}, \bar{C} \hat{\eta}) \hat{\beta}_{\text {enroll }}
$$

For each discrete independent variable, we report the effects from a one-unit change from zero to one. We report robust standard errors that allow for dependence within schools over time. ${ }^{3}$

We begin with school and district determinants in Table 2. We see that enrollments are the most significant determinant of HS closures, and that higher tax rates increase the probability of closure. Concurrent with conventional wisdom, school size and fiscal health are supremely important in the decision to close a school. Perhaps surprisingly, test scores appear to be irrelevant.

Table 3 reports the effects of only community characteristics on high school closures. Community characteristics appear to have substantial explanatory power. Some economic conditions exhibit the expected effects; HS closures are less likely in the presence of high house values. Urbanicity is also important. Relative to rural communities, nearly all other areas are less likely to close a high school. Even controlling for other community characteristics, no areas are more likely to close than rural

\footnotetext{
${ }^{3}$ Since our data include many more open schools than closed schools, random effects probit estimates are unstable. Fortunately, standard probit estimates that allow for error correlation within schools over time provide a suitable substitute.
} 
schools. In addition, youth population has no significant effect on the likelihood of HS closure, which is unexpected.

Table 4 reports the predicted marginal effects for the full specification in (1). Enrollment certainly maintains its relevance. Higher tax rates remain significant, likely reflecting schools that struggle with finances. Otherwise, counties with a relatively less-educated population are more likely to see a HS close. Controlling for additional school characteristics, urban areas remain less likely to close their high school. In sum, the most important determinants of HS closure are location, school tax rates, and enrollment. School quality, as measured by math and test scores, is irrelevant.

Heretofore, our analysis has compared schools that eventually close to those that do not close during our time period. We also exploit the panel nature of the data and investigate the role of lags and trends. Consider the following specification:

$$
\operatorname{Prob}_{\text {closes } \left._{i t}=1\right)}=\operatorname{Prob}\left[\left(\begin{array}{l}
\alpha_{1} \ln \text { enrol }_{i t}+\alpha_{2} \Delta \ln \text { enrol }_{i t-k}+\alpha_{3} \text { eav }_{i t}+\alpha_{4} \Delta e a v_{i t-k} \\
+\alpha_{5} \text { ppex }_{i t}+\alpha_{6} \Delta \operatorname{ppex}_{i t-k}+\alpha_{7} e d f_{i t}+\alpha_{8} \Delta e d f_{i t-k} \\
+\alpha_{9} \text { pop }_{i t}+\alpha_{10} \Delta \operatorname{pop}_{i t-k}+\varepsilon
\end{array}\right)>0\right]
$$

where the dependent variable equals one in the last year the school is open. We assume it is a function of enrollment, EAV per pupil, per-pupil expenditures, education fund tax rate, and schoolage population. All fiscal variables were determined in the prior year's budget, so that the budget decided in year $t-1$ is reported here in the figures in effect for year $t$. We estimate simple trends across the previous 3,5 , and 7 years. In addition, we have estimated probits using lagged values up to five years before closing, but these results are not particularly compelling. 
Estimates for 3- and 7-year trends in equation (4) appear in Table 5. Considering changes over the past three years, we find that enrollment and the education fund are the most important determinants. We further segment our sample into a few "high risk" groups: rural counties, the highest quartile of expenditures, and the lowest quartile of enrolment. Among rural schools, a one percent increase in enrollment decreases the probability of high school closure in that year by $0.4 \%$. In rural counties, nothing matters more than enrollment.

Trends have a limited impact, except the trend for the education fund. School administrators know how pivotal the education fund is in school finance, and our results support this conventional wisdom. If the education fund falls steadily over a number of years, there is a significantly increased risk that a school will close. The importance of the education fund remains in subsamples. For instance, accounting for 7-year trends, a $\$ 1000$ increase in the education fund lowers the probability of a low enrollment school closing by $52 \%$.

\section{Discussion}

School closure decisions, especially those involving a high school, are highly and hotly contested. Some residents often claim that keeping the school open is too costly while others do not want to see a local institution, employer, or hub of activity disappear. The debate among school board members about these decisions often hinges on fiscal issues, taxes, declining enrollments, and academic quality. Existing research also focuses on these issues, highlighting cost savings from closing small schools that cannot benefit from economies of scale, or educational benefits in small schools and their role in communities. 
Illinois has seen many schools close since the early 1970s, and some public officials are calling for more, so Illinois is a prime location for this research. Our paper explores the determinants of high school closure using panel data for all of Illinois except Cook County from 1991 through 2005. This is unique because nearly all extant analyses of closure are case studies or use cross-sectional data. In addition, those studies have not measured the relative contribution of district fiscal issues, school characteristics, the economic health of the local community, and demographics. Using data from a variety of state and federal sources, we explore the importance of all of these factors in a longitudinal context.

We find that lower enrollments and higher taxes are the primary issues faced by schools prior to a closure. This is not surprising. What is surprising is that these effects are significant despite the consideration of numerous other predictors, like test scores, the socio-demographic characteristics of the students, other measures of fiscal health, and characteristics of the local population. It is also surprising that school test scores, student demographics, and other measures of fiscal health have no significant effect on high school closures. Furthermore, three-year trend analysis shows marked relationships between enrollment trajectories and closure decisions. This is true for the entire study population, only those schools in rural counties, and for those with particularly low enrollments.

We find that rurality of a school's location affects closure decisions. This result is robust to additional controls for other factors that the literature describes as associated with rurality (e.g., poverty, unemployment, value of housing, and income). Thus, rural high schools are at a distinct disadvantage. Ceteris paribus, trends in the size and age structure of the local population do not affect closure decisions. 
While this research is the first to examine school closures over such a lengthy period incorporating school, district, and community predictors, much work remains to be done. In addition to high schools, it is valuable to discover the determinants of elementary and junior high school closure decisions, as they may differ from what is reported here. Furthermore, our research agenda will also focus on the consequences of school closures for school districts and their communities. As school consolidation and closure debates continue apace, policymakers and education administrators clearly benefit from ongoing work in this area. 


\section{References}

Albrecht, Don E. 1997. "The Changing Structure of U.S. Agriculture: Dualism Out, Industrialism In.” Rural Sociology. 62:474-490.

Albrecht, Don E. 1998. "The Industrial Transformation of Farm Communities: Implications for Family Structure and Socioeconomic Conditions.” Rural Sociology. 63:51-64.

Arnold, Michael L. (2000). Rural Schools: Diverse Needs Call for Flexible Policies. (Policy Brief), Aurora, Colorado: Mid-Continent Research for Education and Learning. (ERIC Document Reproduction Service No. ED 441 656).

Beale, Calvin L. 1975. The Revival of Population Growth in Nonmetropolitan America. Economic Research Service, ERS-605. Washington, DC: Department of Agriculture.

Beale, Calvin L. 1993. "Salient Features of the Demography of American Agriculture." Pp. 108-127 in The Demography of Rural Life, edited by D.L. Brown, D. Field, and J.J. Zuiches. Publication \#64, University Park, PA: Northeast Regional Center for Rural Development.

Benton, D. (1992). “A Consolidation Success Story.” American School Board Journal, 179(4), 42-43.

Berry, Christopher (October, 2003). "School District Consolidation and Student Outcomes: Does Size Matter?" (Paper presented at the Kennedy School of Government, Harvard University; Cambridge, MA.)

Brasington, David M. 1999. "Joint Provision of Public Goods: The Consolidation of School Districts.” Journal of Public Economics. 73: 373-393.

Brasington, David M. 2003. "Size and School District Consolidation: Do Opposites Attract?" Economica. 70:673-690.

Cochran, Willard W. 1979. The Development of American Agriculture: A Historical Analysis. Minneapolis, MN: University of Minnesota Press.

DeYoung, A. 1995. The Life and Death of a Rural American High School: Farewell Little Kanawha. New York: Garland.

Dorner, Peter. 1983. “Technology and U.S. Agriculture.” Pp. 73-86 in Technology and Social Change in Rural Areas: A Festschrift for Eugene A. Wilkening, edited by G.F. Summers. Boulder, CO: Westview Press.

Economic Research Service. 1997. Rural Conditions and Trends. 8:104.

Edwards, Richard. 1979. "Contested Terrain: The Transformation of the Workplace in the Twentieth Century.” New York: Basic Books. 
Fanning, Jim (August, 1995). "Rural School Consolidation and Student Learning” (ERIC Digest, Report No. EDO-RC-95-4). Charlestown, WV: ERIC/CRESS. (ERIC Document Reproduction Service No. ED 384 484)

Fitchen, Janet M. 1991. Endangered Spaces, Enduring Places: Change, Identity, and Survival in Rural America. Boulder, CO: Westview Press.

Foulkes, Matt and Newbold, Bruce K. 2008. "Poverty Catchments: Migration, Residential Mobility, and Population Turnover in Impoverished Rural Illinois Communities." Rural Sociology. 73:440462.

Gaventa, John, Barbara Ellen Smith, Alex Willingham. 1990. Communities in Economic Crisis: Appalachia and the South. Philadelphia: Temple University Press.

Gordon, Nora, and Brian Knight. 2008 "The Effects of School District Consolidation on Educational Cost and Quality, Public Finance Review, 36(4), pp. 408-430.

Hodson, Randy. 1984. "Companies, Industries and the Measurement of Economic Segmentation." American Sociological Review. 49:335-348.

Johnson, Kenneth M. and Calvin L. Beale. 1994. "The Recent Revival of Widespread Population Growth in Nonmetropolitan Areas of the United States.” Rural Sociology. 59:655-667.

Johnson, Kenneth M., John P. Pelissero, David B. Holian, and Michael T. Maly. 1995. "Local Government Fiscal Burden in Nonmetropolitan America.” Rural Sociology. 60:381-398.

Kannapel, Patricia J. and DeYoung, Alan J. (1999). 'The Rural School Problem in 1999: A Review and Critique of the Literature." Journal of Research in Rural Education, 15 (2) 67-79.

Kassab, Cathy and A.E. Luloff. 1993. "The New Buffalo Hunt: Chasing the Service Sector.” Journal of the Community Development Society. 24:175-195.

Kassab, Cathy, A. E. Luloff, and Fred Schmidt. 1995. "The Changing Impact of Industry, Household Structure, and Residence on Household Well-Being." Rural Sociology. 60:67-90.

Lichter, Daniel T., Domenico Parisi, Steven Michael Grice, and Michael Taquino. 2007. "Municipal Underbounding: Annexation and Racial Exlusion in Small Soouthern Towns." Rural Sociology 72:47-68.

Louisiana Department of Education. 2003. "Small School Districts and Economies of Scale." Presented to the State Board of Elementary and Secondary Education Strategic Planning Study Group Committee. Baton Rouge, LA: Office of Management and Finance; Division of Planning, Analysis, and Information Resources.

Lyson, Thomas A. 2002. "What Does a School Mean to a Community? Assessing the Social and Economic Benefits of to Rural Villages in New York." Journal of Research in Rural Education. 17:131-137. 
Lyson, Thomas. 2005. "Importance of Schools to Rural Community Viability." The Role of Education: Promoting the Economic and Social Vitality of Rural America. (Policy brief). Lionel J. Beaulieu (Ed.). Southern Rural Development Center. Mississippi State University.

McLaughlin, Diane K. and Coleman-Jensen, Alisha J. 2008. "Nonstandard Employment in the Nonmetropolitan United States.”Rural Sociology. 74:631-659

Monk, D.H. \& Haller, E.J. (1986). "Organizational alternatives for small schools.” Ithaca, New York: State University of New York. (ERIC Document Reproduction Service No. ED 281 694).

Nelson, Erik (1985). School Consolidation. (ERIC Digest No. 13, Report No. ED282346). Eugene, OR: Publication Sales, ERIC Clearinghouse on Educational Management.

Noyelle, T.J. 1986. "Economic Transformation.” The Annals. AAPSS. 488:9-17.

Paarlberg, Don. 1980. "Farm and Food Policy: Issues of the 1980s.” Lincoln, NE: University of Nebraska Press.

Ramirez, A. (1992). "Size, Cost, and Quality of Schools and School Districts: A Question of Context." in Source Book on School and District Size, Cost and Quality. (ERIC Document Reproduction Service No. ED 361 162).

Ratcliff, K., B. Riddle, and J.M. Yinger. 1990. "The Fiscal Condition of School Districts in Nebraska: Is Small Beautiful?” Economics of Education Review, 9:81-99.

Reynolds, D. R. 1999. There Goes the Neighborhood: Rural School Consolidation at the Grass Roots in Early Twentieth-Century Iowa. Iowa City, IA: University of Iowa Press.

Summers, Gene F. 1983. Technology and Social Change in Rural Areas: A Festschrift for Eugene A. Wilkening. Boulder, CO: Westview Press.

Summers, Gene F., Sharon D. Evans, Frank Clemente, E. M. Beck, and Jon Minkoff. 1976. Industrial Invasion of Nonmetropolitan America--A Quarter Century of Experience. New York: Praeger.

Tickamyer, Ann R. and Cynthia M. Duncan. 1990. "Poverty and Opportunity Structure in Rural America." Annual Review of Sociology. 16:67-86.

Wilkinson, Kenneth P. 1984. "Rurality and Patterns of Social Disruption." Rural Sociology. 49:21336.

Wilkinson, Kenneth P. 1986. "Communities Left Behind--Again." In Joint Economic Committee’s New Dimensions in Rural Policy: Building Upon Our Heritage. Washington, D.C: U.S. Government Printing Office. 
Figure 1. Median Annual Amounts Leading to High School Closure $\mathrm{T}=0$ is the last year the school was open.
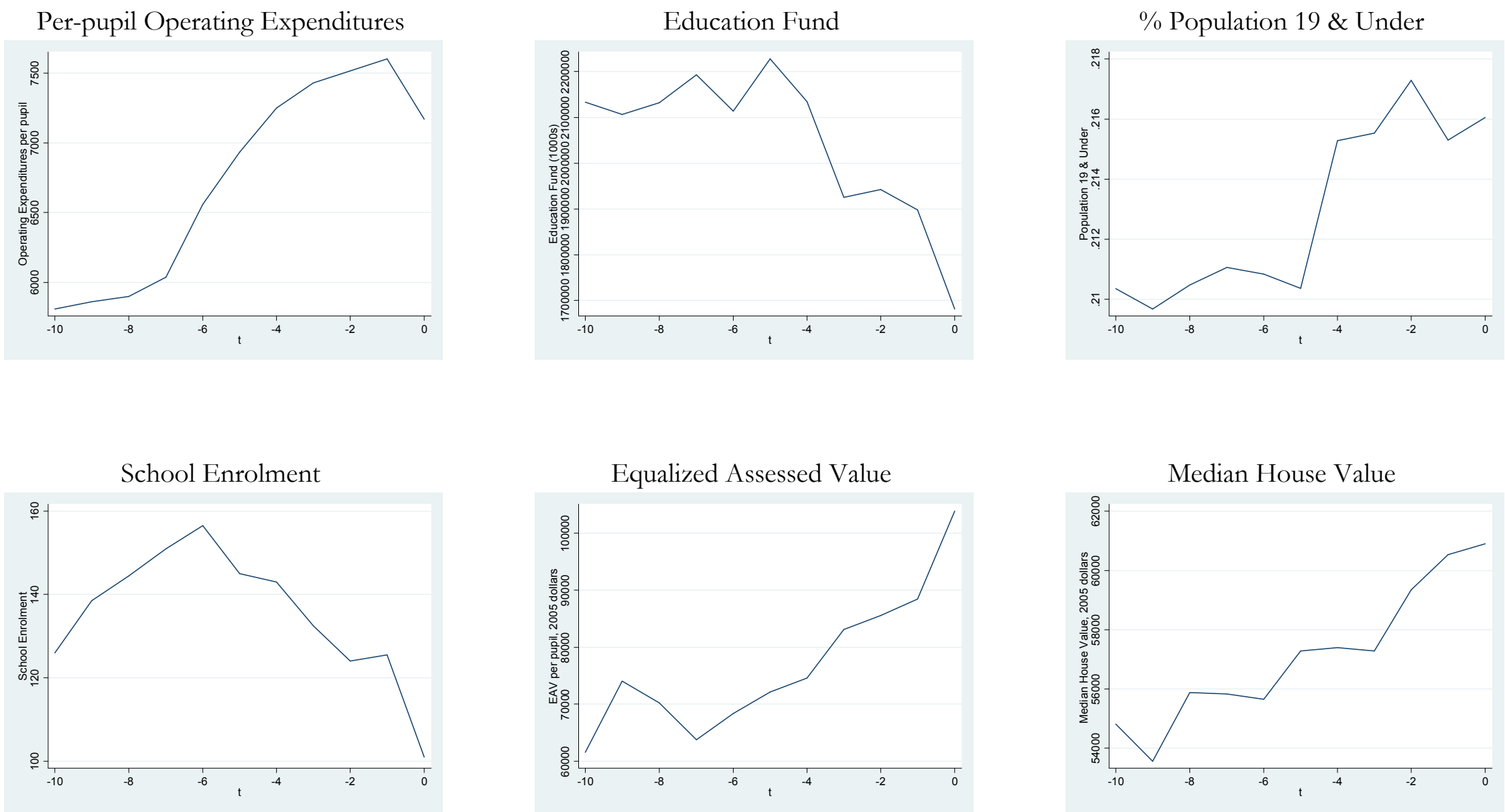
Table 1. Summary Statistics for Illinois High Schools

\begin{tabular}{|c|c|c|c|c|c|}
\hline & \multicolumn{2}{|c|}{ School Closes } & \multicolumn{2}{|c|}{ Open Schools } & \multirow{2}{*}{$\begin{array}{l}\text { Difference in } \\
\text { Means Test }\end{array}$} \\
\hline & Mean & St. Error & Mean & St. Error & \\
\hline \multicolumn{6}{|l|}{ School Characteristics } \\
\hline Enrollment & 201.63 & 15.21 & 688.95 & 8.94 & $12.77 * * *$ \\
\hline$\%$ Black Students & 6.12 & 1.86 & 4.85 & 0.17 & 1.65 \\
\hline$\%$ Latino Students & 0.76 & 0.09 & 2.93 & 0.09 & $5.74 * * *$ \\
\hline \% Low Income Students & 22.47 & 0.81 & 17.92 & 0.19 & $5.62 * * *$ \\
\hline Attendance Rate & 93.62 & 0.13 & 93.55 & 0.03 & 0.55 \\
\hline Dropout Rate & 3.91 & 17.00 & 3.52 & 0.03 & $2.59 * * *$ \\
\hline Math, Does Not Meet Goals & 30.77 & 1.17 & 32.51 & 0.25 & 1.59 \\
\hline Math, Exceeds Goals & 13.77 & 0.69 & 14.56 & 0.17 & 1.08 \\
\hline Reading, Does Not Meet Goals & 33.05 & 0.87 & 32.90 & 0.17 & 0.2 \\
\hline Reading, Exceeds Goals & 19.26 & 0.71 & 18.23 & 0.15 & 1.57 \\
\hline \multicolumn{6}{|l|}{ District Characteristics } \\
\hline Pupil-Teacher Ratio & 12.08 & 0.21 & 16.08 & 0.05 & $18.58 * * *$ \\
\hline EAV per Pupil & $8.02 \mathrm{E}+04$ & $3.31 \mathrm{E}+03$ & $1.36 \mathrm{E}+05$ & $2.23 \mathrm{E}+03$ & $5.56 * * *$ \\
\hline School Tax Rate & 4.55 & 0.07 & 3.92 & 0.02 & $6.79 * * *$ \\
\hline Education Fund & $5.65 \mathrm{E}+06$ & $8.33 \mathrm{E}+05$ & $1.64 \mathrm{E}+07$ & $3.85 \mathrm{E}+05$ & $6.56 * * *$ \\
\hline Per-pupil Expenditures & 6969.30 & 80.80 & 7268.66 & 26.45 & $2.63 * * *$ \\
\hline Teacher Salary & 38231.83 & 393.00 & 46834.84 & 138.00 & $14.47 * * *$ \\
\hline High School District & 0.10 & 0.02 & 0.18 & 0.01 & $4.12 * * *$ \\
\hline \multicolumn{6}{|l|}{ Town Characteristics } \\
\hline Povery Rate & 2.13 & 0.09 & 1.21 & 0.03 & $6.71 * * *$ \\
\hline \% Population Rural & 76.85 & 2.25 & 42.65 & 0.62 & $12.64 * * *$ \\
\hline Median House Value & 60800.75 & 1095.00 & 97066.69 & 896.00 & $9.50 * * *$ \\
\hline Vacancy Rate O-O Housing & 8.23 & 0.17 & 6.80 & 0.04 & $7.93 * * *$ \\
\hline Median Household Income & 37447.93 & 434.00 & 45504.73 & 219.00 & $8.62 * * *$ \\
\hline \multicolumn{6}{|l|}{ County Characteristics } \\
\hline Census Designated Metro & 0.26 & 0.02 & 0.46 & 0.01 & $7.07 * * *$ \\
\hline \% Population 19 \& Under & 0.22 & 0.001 & 0.23 & 0.0002 & $8.25 * * *$ \\
\hline Unemployment Rate & 5.64 & 0.10 & 5.70 & 0.02 & 0.53 \\
\hline \% Pop HS Diploma & 38.61 & 0.28 & 34.69 & 0.08 & $11.34 * * *$ \\
\hline$\%$ Pop BA/BS & 10.42 & 0.25 & 12.07 & 0.07 & $5.44 * * *$ \\
\hline Tax Capped County & 0.05 & 0.01 & 0.14 & 0.004 & $4.91 * * *$ \\
\hline Number of Schools & 52 & & 496 & & \\
\hline
\end{tabular}

Data: ISBE, Census, BLS, IDES, 1991-2005. Illinois schools excluding Cook County, all dollars real 2005. Absolute t-statistics reported for difference in means tests. Asterisks denote standard confidence levels. 
Table 2. The Effect of School Characteristics on the Probability of High School Closure

Ln(Enrollment)

Real EAV per pupil, (mils)

Per Pupil Expenditures (1000s)

School Tax Rate

Teacher Salary

Education Fund Rate

\% Latino Students

$\%$ Black Students

\% Low Income Students

Percent not Meeting Math Test Goals

Percent Exceeding Math Test Goals

Percent not Meeting Reading Test Goals

Percent Exceeding Reading Test Goals
(1)

(2)

$-0.0296^{* *}$
$(0.0086)$
-0.0401
$(0.0749)$
0.0035
$(0.0032)$
$0.0101 * *$
$(0.0050)$
-0.0416
$(0.0879)$
.0004

$(0.0003)$
(3)

\begin{tabular}{|c|c|c|}
\hline \multirow{12}{*}{$\begin{array}{l}-0.0412 * * * \\
(0.0099)\end{array}$} & $-0.0308 * * *$ & $-0.0309 * * *$ \\
\hline & $(0.0101)$ & $(0.0101)$ \\
\hline & -0.0230 & -0.0262 \\
\hline & $(0.0660)$ & $(0.0671)$ \\
\hline & 0.0019 & 0.0024 \\
\hline & $(0.0026)$ & $(0.0028)$ \\
\hline & $0.0096 * *$ & $0.0094 *$ \\
\hline & $(0.0049)$ & $(0.0049)$ \\
\hline & -0.0302 & -0.0279 \\
\hline & $(0.1009)$ & $(0.1010)$ \\
\hline & .0004 & .0004 \\
\hline & $(0.0003)$ & $(0.0003)$ \\
\hline-0.0007 & -0.0005 & -0.0005 \\
\hline$(0.0010)$ & $(0.0007)$ & $(0.0007)$ \\
\hline 0.0006 & 0.0003 & 0.0004 \\
\hline$(0.0004)$ & $(0.0004)$ & $(0.0004)$ \\
\hline-0.0002 & -0.0001 & -0.0001 \\
\hline$(0.0003)$ & $(0.0003)$ & $(0.0003)$ \\
\hline & & -0.0001 \\
\hline & & $(0.0001)$ \\
\hline & & -0.0003 \\
\hline & & $(0.0003)$ \\
\hline & & -0.0001 \\
\hline & & $(0.0001)$ \\
\hline & & 0.0003 \\
\hline & & $(0.0002)$ \\
\hline 0.204 & 0.239 & 0.242 \\
\hline 6213 & 6213 & 6213 \\
\hline
\end{tabular}

Pseudo R-squared

0.233 6213

$\mathrm{N}=5946$, standard errors in parentheses, $*$ significant at $10 \% ; * *$ significant at $5 \% ; * * *$ significant at $1 \%$
Additional variables: teacher experience, pupil-teacher ratio, HS district indicator, missing indicator. Data: Illinois State Board of Education, 1991-2005. Illinois high schools outside of Cook County. 
Table 3. The Impact of Community Characteristics on the Probability of High School Closure

\begin{tabular}{|c|c|c|}
\hline & $(1)$ & $(2)$ \\
\hline \multirow[t]{2}{*}{ Median House Value (10000s) } & $-0.0114 * * *$ & $-0.0068 * * *$ \\
\hline & $(0.0025)$ & $(0.0020)$ \\
\hline \multirow[t]{2}{*}{ Poverty Rate } & -0.0004 & -0.0004 \\
\hline & $(0.0009)$ & $(0.0008)$ \\
\hline \multirow[t]{2}{*}{ Median HH Income (10000s) } & $0.0139 *$ & 0.0029 \\
\hline & $(0.0074)$ & $(0.0054)$ \\
\hline \multirow[t]{2}{*}{ Population $19 \&$ Under } & -0.2400 & -0.2147 \\
\hline & $(0.1474)$ & $(0.1374)$ \\
\hline \multirow[t]{2}{*}{ Unemployment Rate } & $-0.0052 * *$ & 0.0001 \\
\hline & $(0.0021)$ & $(0.0014)$ \\
\hline \multirow{2}{*}{ Metro Metro $>1$ million } & -0.0023 & 0.0039 \\
\hline & $(0.0192)$ & $(0.0159)$ \\
\hline \multirow[t]{2}{*}{ Metro $250 \mathrm{k}$ to 1 million } & $-0.0243 * * *$ & $-0.0151 * *$ \\
\hline & $(0.0087)$ & $(0.0066)$ \\
\hline \multirow[t]{2}{*}{ Metro $<250 \mathrm{k}$} & -0.0075 & -0.0107 \\
\hline & $(0.0152)$ & $(0.0074)$ \\
\hline \multirow[t]{2}{*}{ Urban $>20 \mathrm{k}$, Metro-Adjacent } & $-0.0152 *$ & -0.0084 \\
\hline & $(0.0089)$ & $(0.0071)$ \\
\hline \multirow[t]{2}{*}{ Urban $>20 \mathrm{k}$, not Metro-Adjacent } & $-0.0181 * *$ & $-0.0126 * *$ \\
\hline & $(0.0071)$ & $(0.0053)$ \\
\hline \multirow[t]{2}{*}{ Urban $>2500$, Metro-Adjacent } & $-0.0184 *$ & $-0.0127 *$ \\
\hline & $(0.0108)$ & $(0.0077)$ \\
\hline \multirow[t]{2}{*}{ Urban $>2500$, not Metro-Adjacent } & -0.0018 & 0.0025 \\
\hline & $(0.0162)$ & $(0.0142)$ \\
\hline \multirow[t]{2}{*}{ Population with HS Diploma } & & $0.0035^{* *}$ \\
\hline & & $(0.0014)$ \\
\hline \multirow[t]{2}{*}{ Population with BA/BS } & & $0.0037 * *$ \\
\hline & & $(0.0017)$ \\
\hline \multirow[t]{2}{*}{ Population with Grad Degree } & & 0.0030 \\
\hline & & $(0.0019)$ \\
\hline \multirow[t]{2}{*}{ County Has Property Tax Cap } & & $-0.0119 * *$ \\
\hline & & $(0.0052)$ \\
\hline Pseudo R-squared & 0.157 & .225 \\
\hline Number of Observations & 6213 & 6213 \\
\hline
\end{tabular}

Standard errors in parentheses, * significant at 10\%; ** significant at 5\%; *** significant at $1 \%$ Additional variables: \% employed in agriculture, \% immigrant, O-O vacancy rate.

Data: U.S. Census, BLS, IDES, 1991-2005. 
Table 4. Full Specification Estimates for the Likelihood of High School Closure

\begin{tabular}{|c|c|c|c|}
\hline Ln(Enrollment) & $\begin{array}{l}-0.0126^{* *} \\
(0.0054)\end{array}$ & Percent not Meeting Math Test Goals & $\begin{array}{l}-0.0001 \\
(0.0001)\end{array}$ \\
\hline Real EAV per pupil, (mils) & $\begin{array}{l}0.0024 \\
(0.0140)\end{array}$ & Percent Exceeding Math Test Goals & $\begin{array}{l}-0.0001 \\
(0.0001)\end{array}$ \\
\hline Per Pupil Expenditures (1000s) & $\begin{array}{l}0.0012 \\
(0.0014)\end{array}$ & Percent not Meeting Reading Test Goals & $\begin{array}{l}-0.0000 \\
(0.0001)\end{array}$ \\
\hline School Tax Rate & $\begin{array}{l}0.0039^{*} \\
(0.0023)\end{array}$ & Percent Exceeding Reading Test Goals & $\begin{array}{l}0.0001 \\
(0.0001)\end{array}$ \\
\hline Teacher Salary & $\begin{array}{l}0.0342 \\
(0.0422)\end{array}$ & Unemployment Rate & $\begin{array}{l}-0.0003 \\
(0.0007)\end{array}$ \\
\hline Education Fund Rate & $\begin{array}{l}0.0001 \\
(0.0001)\end{array}$ & Metro Metro $>1$ million & $\begin{array}{l}-0.0002 \\
(0.0077)\end{array}$ \\
\hline \% Latino Students & $\begin{array}{l}0.0001 \\
(0.0004)\end{array}$ & Metro $250 \mathrm{k}$ to 1 million & $\begin{array}{l}-0.0085^{* *} \\
(0.0044)\end{array}$ \\
\hline$\%$ Black Students & $\begin{array}{l}0.0001 \\
(0.0001)\end{array}$ & Metro $<250 \mathrm{k}$ & $\begin{array}{l}-0.0048 \\
(0.0048)\end{array}$ \\
\hline$\%$ Low Income Students & $\begin{array}{l}-0.0002 \\
(0.0001)\end{array}$ & Urban $>20 \mathrm{k}$, Metro-Adjacent & $\begin{array}{l}-0.0060^{*} \\
(0.0034)\end{array}$ \\
\hline Average Teacher Experience & $\begin{array}{l}-0.0010 \\
(0.0008)\end{array}$ & Urban $>20 \mathrm{k}$, not Metro-Adjacent & $\begin{array}{l}-0.0065^{* *} \\
(0.0032)\end{array}$ \\
\hline Pupil-Teacher Ratio & $\begin{array}{l}-0.0003 \\
(0.0006)\end{array}$ & Urban $>2500$, Metro-Adjacent & $\begin{array}{l}-0.0093^{*} \\
(0.0050)\end{array}$ \\
\hline \% Employed in Agriculture & $\begin{array}{l}-0.0014 \\
(0.0009)\end{array}$ & Urban $>2500$, not Metro-Adjacent & $\begin{array}{l}-0.0023 \\
(0.0053)\end{array}$ \\
\hline$\%$ Immigrant & $\begin{array}{l}0.0001 \\
(0.0007)\end{array}$ & Population with HS Diploma & $\begin{array}{l}0.0016^{*} \\
(0.0009)\end{array}$ \\
\hline Median House Value (10000s) & $\begin{array}{l}-0.0028^{* *} \\
(0.0013)\end{array}$ & Population with BA/BS & $\begin{array}{l}0.0013 \\
(0.0009)\end{array}$ \\
\hline Poverty Rate & $\begin{array}{l}-0.0015^{*} \\
(0.0009)\end{array}$ & Population with Grad Degree & $\begin{array}{l}0.0013 \\
(0.0010)\end{array}$ \\
\hline Median HH Income (10000s) & $\begin{array}{l}-0.0018 \\
(0.0033)\end{array}$ & County Has Property Tax Cap & $\begin{array}{l}-0.0054 \\
(0.0033)\end{array}$ \\
\hline Population 19 \& Under & $\begin{array}{l}-0.0804 \\
(0.1048)\end{array}$ & & \\
\hline
\end{tabular}

$\mathrm{N}=6213$, standard errors in parentheses. $*$ significant at 10\%; ** significant at 5\%; *** significant at $1 \%$ Data: Illinois State Board of Education, 1991-2005. Illinois high schools outside of Cook County. Additional variables: O-O vacancy rate, HS district indicator, missing data indicator. 
Table 5. Probit Results on Probability of High School Closure, Select Subgroups

\begin{tabular}{|c|c|c|c|c|c|c|c|c|}
\hline & \multicolumn{4}{|c|}{ Three Year Trends } & \multicolumn{4}{|c|}{ Seven Year Trends } \\
\hline & All & $\begin{array}{l}\text { Rural } \\
\text { Counties } \\
\end{array}$ & $\begin{array}{l}\text { Highest } \\
\text { Expenditure }\end{array}$ & $\begin{array}{l}\text { Lowest } \\
\text { Enrollment }\end{array}$ & All & $\begin{array}{l}\text { Rural } \\
\text { Counties }\end{array}$ & $\begin{array}{l}\text { Highest } \\
\text { Expenditure }\end{array}$ & $\begin{array}{l}\text { Lowest } \\
\text { Enrollment } \\
\end{array}$ \\
\hline Ln(Enrollment) & $\begin{array}{l}-0.0007 * * \\
(0.0003)\end{array}$ & $\begin{array}{l}-0.0035 * * \\
(0.0016)\end{array}$ & $\begin{array}{l}-0.0006 \\
(0.0010)\end{array}$ & $\begin{array}{l}-0.0089 * * \\
(0.0038)\end{array}$ & $\begin{array}{l}-0.0008 \\
(0.0016)\end{array}$ & $\begin{array}{l}-0.0023 \\
(0.0019)\end{array}$ & $\begin{array}{l}-0.0013 \\
(0.0016)\end{array}$ & $\begin{array}{l}-0.0136^{* *} \\
(0.0067)\end{array}$ \\
\hline Real EAV per pupil, (mils) & $\begin{array}{l}-8.33 e-05 \\
(0.002)\end{array}$ & $\begin{array}{l}0.0098 \\
(0.0093)\end{array}$ & $\begin{array}{l}-0.0266^{*} \\
(0.0150)\end{array}$ & $\begin{array}{l}-0.0801 * \\
(0.0454)\end{array}$ & $\begin{array}{l}-0.0498 \\
(0.0327)\end{array}$ & $\begin{array}{l}-0.0408 \\
(0.0309)\end{array}$ & $\begin{array}{l}-0.0404 \\
(0.0282)\end{array}$ & $\begin{array}{l}-0.0528 \\
(0.0609)\end{array}$ \\
\hline Per Pupil Expenditures (1000s) & $\begin{array}{l}3.84 \mathrm{e}-05 \\
(0.0001)\end{array}$ & $\begin{array}{l}-0.0007 \\
(0.0005)\end{array}$ & $\begin{array}{l}0.0014 * * \\
(0.0006)\end{array}$ & $\begin{array}{l}-0.0014 \\
(0.0009)\end{array}$ & $\begin{array}{l}0.0013 \\
(0.0016)\end{array}$ & $\begin{array}{l}-4.23 e-05 \\
(0.0012)\end{array}$ & $\begin{array}{l}0.0020 \\
(0.0015)\end{array}$ & $\begin{array}{l}-0.0018 \\
(0.0022)\end{array}$ \\
\hline Education Fund Rate & $\begin{array}{l}.0001 * * * \\
(4.35 \mathrm{e}-05)\end{array}$ & $\begin{array}{l}.0001 \\
(.0001)\end{array}$ & $\begin{array}{l}.00001 \\
(6.99 e-06)\end{array}$ & $\begin{array}{l}.0002 \\
(.0001)\end{array}$ & $\begin{array}{l}3.75 e-05 \\
(4.11 e-05)\end{array}$ & $\begin{array}{l}.0001 \\
(.0002)\end{array}$ & $\begin{array}{l}1.10 \mathrm{e}-06 \\
(3.31 \mathrm{e}-06)\end{array}$ & $\begin{array}{l}-4.35 \mathrm{e}-06 \\
(2.44 \mathrm{e}-05)\end{array}$ \\
\hline Population $19 \&$ Under & $\begin{array}{l}0.0015 \\
(0.0064)\end{array}$ & $\begin{array}{l}0.0042 \\
(0.0327)\end{array}$ & $\begin{array}{l}0.0327 \\
(0.0402)\end{array}$ & $\begin{array}{l}0.0307 \\
(0.0574)\end{array}$ & $\begin{array}{l}0.115 \\
(0.0826)\end{array}$ & $\begin{array}{l}0.0789 \\
(0.0728)\end{array}$ & $\begin{array}{l}0.0669 \\
(0.0764)\end{array}$ & $\begin{array}{l}0.158 \\
(0.133)\end{array}$ \\
\hline Enrolment Trend & $\begin{array}{l}-3.54 \mathrm{e}-06^{*} \\
(1.91 \mathrm{e}-06)\end{array}$ & $\begin{array}{l}-1.46 \mathrm{e}-05 \\
(1.16 \mathrm{e}-05)\end{array}$ & $\begin{array}{l}8.08 \mathrm{e}-07 \\
(4.15 \mathrm{e}-06)\end{array}$ & $\begin{array}{l}-5.20 \mathrm{e}-05 \\
(5.83 \mathrm{e}-05)\end{array}$ & $\begin{array}{l}-3.64 \mathrm{e}-07 \\
(1.01 \mathrm{e}-05)\end{array}$ & $\begin{array}{l}-1.23 \mathrm{e}-05 \\
(2.04 \mathrm{e}-05)\end{array}$ & $\begin{array}{l}-1.23 e-06 \\
(3.87 e-06)\end{array}$ & $\begin{array}{l}4.09 \mathrm{e}-05 \\
(3.49 \mathrm{e}-05)\end{array}$ \\
\hline Education Fund Trend & $\begin{array}{l}-6.27 e-05^{*} \\
(3.66 e-05)\end{array}$ & $\begin{array}{l}-0.0001 \\
(9.10 \mathrm{e}-05)\end{array}$ & $\begin{array}{l}-0.0002 * \\
(0.0001)\end{array}$ & $\begin{array}{l}6.24 \mathrm{e}-07 \\
(0.0001)\end{array}$ & $\begin{array}{l}-0.0002 \\
(0.0002)\end{array}$ & $\begin{array}{l}0.0002 * \\
(0.0001)\end{array}$ & $\begin{array}{l}1.94 \mathrm{e}-05 \\
(4.22 \mathrm{e}-05)\end{array}$ & $\begin{array}{l}0.0002 \\
(0.0001)\end{array}$ \\
\hline Population Trend & $\begin{array}{l}0.0120 \\
(0.0138)\end{array}$ & $\begin{array}{l}0.0861 \\
(0.0781)\end{array}$ & $\begin{array}{l}-0.0147 \\
(0.0337)\end{array}$ & $\begin{array}{l}-0.0702 \\
(0.0678)\end{array}$ & $\begin{array}{l}-0.0621 \\
(0.169)\end{array}$ & $\begin{array}{l}0.0082 \\
(0.126)\end{array}$ & $\begin{array}{l}0.0108 \\
(0.0812)\end{array}$ & $\begin{array}{l}-0.322 \\
(0.260)\end{array}$ \\
\hline Observations & 4979 & 1874 & 1227 & 1064 & 2232 & 589 & 983 & 628 \\
\hline
\end{tabular}

Standard errors in parentheses, $* * * \mathrm{p}<0.01, * * \mathrm{p}<0.05, * \mathrm{p}<0.1$ Regressions include high school district indicator.

Data: ISBE, Census, BLS, IDES, 1991-2006. Illinois high schools outside of Cook County are included in the analysis. 